\title{
Rhynchosporium species on Finnish grasses
}

\author{
Kaiho M $\ddot{a} k e l \ddot{a}$
}

Department of Plant Pathology, University of Helsinki. Viikki, 00710 Helsinki 71, Finland

\begin{abstract}
The material (c. 2800 samples) for this study was collected from planted grassland or the borders of fields throughout the conutry in 1966-1970.

Rhynchosporium orthosporum Caldwell was observed to occur commonly on cultivated and wild grasses in many localities from Helsinki to Lapland. Spores of the fungus were most abundant in the leaves of the grass in early spring and were least abundant in mid summer.

$R$. orthosporum was the most common causer of leaf spot diseases on Dactylis glomerata $\mathrm{L}$., during the growing season and in part also under the snow. It was also common on Alopecurus pratensis L., especially towards the beginning of the growing season. $R$. orthosporum also occurred commonly on Phleum pratense L., Festuca pratensis Huds., Lolium perenne L., Poa pratensis L. and Festuca rubra L. On these grasses the significance of $R$. orthosporum was smaller than on the grasses first mentioned.

In addition native spores of $R$. orthosporum were found sporadically on the following species of grass: Agrostis stolonifera L., A tenuis Sibth., Alopecurus geniculatus L., Calamagrostis arundinaceae (L.) Roth., C. epigeios (L.) Roth., Deschampsia caespitosa (L.) PB., Lolium multiflorum Lam. and Poa annua L.

Rhynchosporium secalis (Oud.) Davis was observed rather commonly on Agropyron repens (L.) PB. and sporadically on Bromus inermis Leyss.
\end{abstract}

\section{Introduction}

Rhynchosporium Heinsen is a genus of Moniliales. Two species have been described. $R$. secalis (Oud.) Davis is the causer of leaf blotch of barley, rye and certain grasses. $R$. orthosporus Caldwell produced scald-like blotches on many wild and cultivated grasses (Caldwell 1937, Sprague 1950). The fungi are characterized by a very sparse mycelium which ramifies throughout the tissues lying immediately below the cuticle. The conidia are elongated and generally once-septate. $R$. orthosporum has cylindrical conidia which differentiate it from $R$. secalis, which has apically beaked conidia (CALDwell 1937). Both species thrive in humid, rainy and cool wheather (Caldwell 1937, Skoropad 1957,
Latch \& Wenham 1959, Latch 1966). A high degree of host specialization has been found within the species $R$. secalis (CALDwell 1937, Schein 1958, Kajiwara \& Iwata 1963).

Rhynchosporium secalis (Oud.) Davis, Trans. Wisc. Acad. Sci. 20: 413, 1921; Syn. Marssonia secalis, Oudemans, Konink. Akad. Wetensch. 6: 88, 1897; $R$. graminicola Heinsen, Jahrb. Hamburg. Wiss. Anst. 18, 3: 43, 1901; (cf. Lindau 1910: 757). The fungus has often been reported on grass species, e.g. on Agropyron repens. (L.) PB. in Denmark (Lind 1913), in Norway (Jørstad 1930, 1945, Hansen \& Magnus 1969), in Britain (Owen 1952), in the USA (Caldwell 1929, 1931, 1937) and in New Zealand (BrIEN 1942), on Agrostis stolonifera L. in the Neth- 


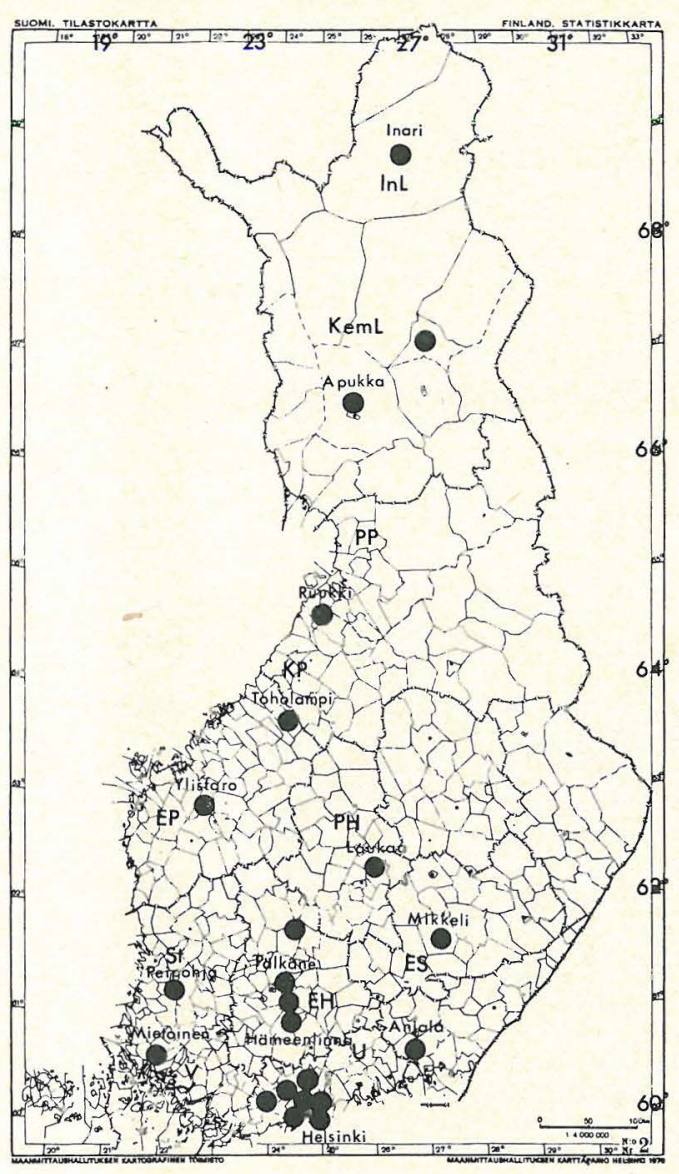

Fig. 1. Origin of the material.

erlands (ANON 1961) and in the USA (Sprague 1950), on Alopecurus pratensis L. in Norway (Hansen \& Magnus 1969), on Bromus inermis Leyss. in the USA (DRECHSLER 1921, Caldowell 1929, 1931, 1937, Sprague 1950), in Germany (MüHLE 1953) and in Norway (Hansen \& Magnus 1969), on $B$. mollis L. (Brooks 1929, Owen 1952) and $B$. sterilis L. (Brooks 1928) in Britain, on Dactylis glomerata L. in the USA (DRECHSLER 1921) and in Britain (Brooks 1928, on Lolium multiflorum f. sp. westerwoldicum in Britain (THORPe 1960), and on L. perenne L. in Germany (BARTELS 1928), and in the USA (Howard et al. 1951).

Rhynchosporium orthosporum Caldwell, J. Agric. Res. 55: 184, 1937. The fungus was recorded on Dactylis glomerata L. in the USA for the first time (CALDWELL 1931, 1937). Thereafter this fungus has been re- ported on this grass species e.g. in the USA (Sprague 1950, Elliott 1962), in Britain (Owen 1952), in Denmark (SMedegård-PeTERSEN 1970), in New Zeeland (LATch \& Wenham 1959) and in Japan (Kajiwara \& Iwata 1963). The fungus frequently attacks Lolium perenne L. in New Zealand (LATCH 1966). It was recorded on this grass also in the USA (Sprague 1946) and in Britain (Fowler \& OWEN 1964). R. orthosporum was found on L. multiflorum Lam. in the USA (Sprague 1946), in Britain (Wilcox 1960) and on this species and on L. multiflorum f. sp. westerwoldicum in New Zealand (LATch 1956), as well as on Agrostis stolonifera L., Alopecurus pratensis L. and Calamagrostis canadensis (Michx.) Beauv. in the USA (Sprague 1946).

This study is part of a broad research project dealing with spot diseases on grasses growing on leys, with the pathogens causing these diseases (cf. M̈̈KEL Ä 1970, 1971, 1972a). The study has been in progress at the Department of Plant Pathology, University of Helsinki at Viikki ever since 1966. The purpose of the present study is to clarify the occurrence of Rhynchosporium species on the most important grasses.

\section{Materials and Methods}

Grass samples were collected during the period between spring thaw and the first heavy snow-fall in autumn from 1966 to 1970. The grasses (c. 2800 samples) were collected from planted grassland and the borders of fields in many localities throughout the country (Fig. 1). Conidia produced in natural infestations were examined. The slides of the fungus material were prepared from fresh grass leaves. The fungi on the slides were preserved in lactic-acid and lactophenol solutions with trypanblue. The conidia were also measured and photographed on the slides. The fungus was not grown in pure culture.

\section{Results and Discussion}

In this study Rhynchosporium orthosporum was the dominant species on grasses. By comparison $R$. secalis was found in very small quantity and only on a few species of grass. 
$R$. orthosporum was observed in a good $40 \%$ of the grass samples that were collected throughout the country (c. 2670 samples). The fungus was most common on cocksfoot (Dactylis glomerata), occurring in over $70 \%$ of the samples examined (c. 760 samples). On timothy (Phleum pratense) and on meadow fescue (Festuca pratensis) the fungus occurred to a considerably lesser extent, in about $1 / 3$ of the samples examined. For the other grass species (Festuca rubra, Lolium perenne, Poa pratensis) there were fewer samples from fewer localities. Of these, $R$. orthosporum was observed in $1 / 4-1 / 5$ of the samples. On meadow foxtail (Alopecurus pratensis) Rhynchosporium spp. occurred in about $40 \%$ of the samples (c. 170 samples).

Rhynchosporium orthosporum was furthermore observed sporadically in certain other grass spcies.

\section{Material examined}

On Agrostis stolonifera L.:

U: Viikki 24. XI. 1967, 28. III. 1968, 17. V. 1968, 9. IX. 1968, Hyrylä 29. V. 1970; EH: Hämeenlinna 11. V. 1967, 31. V. 1968.

On Agrostis tenuis Sibth.:

U: Viikki 30. VI. 1970, 12. X. 1970, Hyrylä 29. V. 1970; EH: Juupajoki 17. VIII. 1970, Hämeenlinna 3.IV. 1968, 25. V. 1969; InL: Inari 28. VII. 1969, 12. VI. 1970.

On Alopecurus geniculatus L.:

U: Viikki 21. IV. 1967, 6. V. 1970 , 19. V. 1970; St: Peipohja 15. V. 1968, 27. VI. 1968.

On Alopecurus pratensis L.:

U: Helsinki, Viikki (40 specimens), Hyrylä (3 specimens); EH: Hämenlinna (4 specimens); ES: Mikkeli (2 specimens); InL: Inari (14 specimens).

\section{On Calamagrostis arundinaceae (L.) Roth.: \\ U: Lohja 15. VIII. 1968.}

On Calamagrostis epigeios (L.) Roth.:

U: Helsinki, Viikki 28. VIII. 1969, Espoo 15. VIII. 1968, Nummela 15. VIII. 1968; EH: Hämeenlinna 23. VI. 1968; InL: Inari 22. VII. 1968.

\section{On Dactylis glomerata L.:}

U: Helsinki, Viikki (322 specimens), Tikkurila (21 specimens), Hyrylä (9 specimens); V: Mietoinen (25 specimens); EK: Anjala ( 7 specimens); EH: Hämeenlinna (21 specimens), Pälkäne (13 specimens); St: Peipohja (40 specimens); ES: Mikkeli (49 specimens); PH: Laukaa (13 specimens); EP: Ylistaro (9 specimens); KP: Toholampi (13 specimens); InL: Inari (4 specimens).

On Deschampsia caespitosa (L.) PB.:

U: Helsinki, Viikki 4.VI. 1968; ES: Mikkeli 21. V. 1968; KemL: Pelkosenniemi 21. VII. 1970,
4. VIII. 1970; InL: Inari 13. VI. 1969, 28. VII. 1969, 18. VI. 1970.

\section{On Festuca pratensis Huds.:}

U: Helsinki, Viikki (109 specimens), Tikkurila (23 specimens), Hyrylä (1 specimen); V: Mietoinen (19 specimens); EK: Anjala (4 specimens); EH: Hämenlinna (5 specimens), Pälkäne (4 specimens); St: Peipohja (27 specimens); ES: Mikkeli (14 specimens); PH: Laukaa (5 specimens); EP: Ylistaro (6 specimens); KP: Toholampi (9 specimens), PP: Ruukki (3 specimens); InL: Inari (2 specimens).

On Festuca rubra L.:

U: Helsinki, Viikki (17 specimens), Hyrylä (1 specimen); EH: Hämenlinna (1 specimen); St: Peipohja (1 specimen); InL: Inari (4 specimens).

On Lolium multiflorum Lam.:

U: Helsinki, Viikki 17. IX. 1968; PP: Ruukki 24. IX. 1969, 16. VII. 1970, 3. IX. 1970, Apukka 1.X. 1969; InL: Inari 12. VI. 1970.

On Lolium perenne L.:

U: Helsinki, Viikki (28 specimens), Hyrylä (1 specimen); St: Peipohja (4 specimens); InL: Inari (2 specimens)

On Phleum pratense L.:

U: Helsinki, Viikki (98 specimens), Tikkurila (7 specimens), Hyrylä (1 specimen); V: Mietoinen (5 specimens); EH: Hämeenlinna (24 specimens); St: Peipohja (5 specimens); ES: Mikkeli (5 specimens); KP: Toholampi (2 specimens); PP: Ruukki (11 specimens); InL: Inari (15 specimens).

On Poa annua L:

EH: Lepaa 4. IX. 1970; ES: Mikkeli 21. V. 1968; InL: Inari 1. IX. 1968, 22. VII. 1969.

On Poa pratensis L.:

U: Helsinki, Viikki (15 specimens), Hyrylä (4 specimens); EH: Hämeenlinna ( 3 specimens); St: Peipohja (1 specimen); ES: Mikkeli (1 specimen); InL: Inari (5 specimens).

All the samples in the Collection of HPP, in $1966-1970$.

Rhynchosporium secalis was not positively identified on cultivated grasses at all. On native grasses the fungus was observed rather commonly on Agropyron repens (L.) PB. In addition the fungus was found sporadically on Bromus inermis Leyss. as follows:

\section{On Agropyron repens (L.) PB.:}

U: Helsinki, Viikki 17. V. 1967, 20. V. 1970 , Kirkkonummi 15. VIII. 1968; EH: Lepaa 11. V. 1967, 17. V. 1970, Hämeenlinna 11. V. 1967, 3. XI. 1967, 18. X. 1969, 4. VII. 1970; ES: Mikkeli 21. V. 1968, 28. VI. 1968; InL: Inari 31. VII. 1970.

On Bromus inermis Leyss.:

U: Helsinki, Viikki 26. V.1967, 28. V. 1970.

All the samples in the Collection of HPP. 


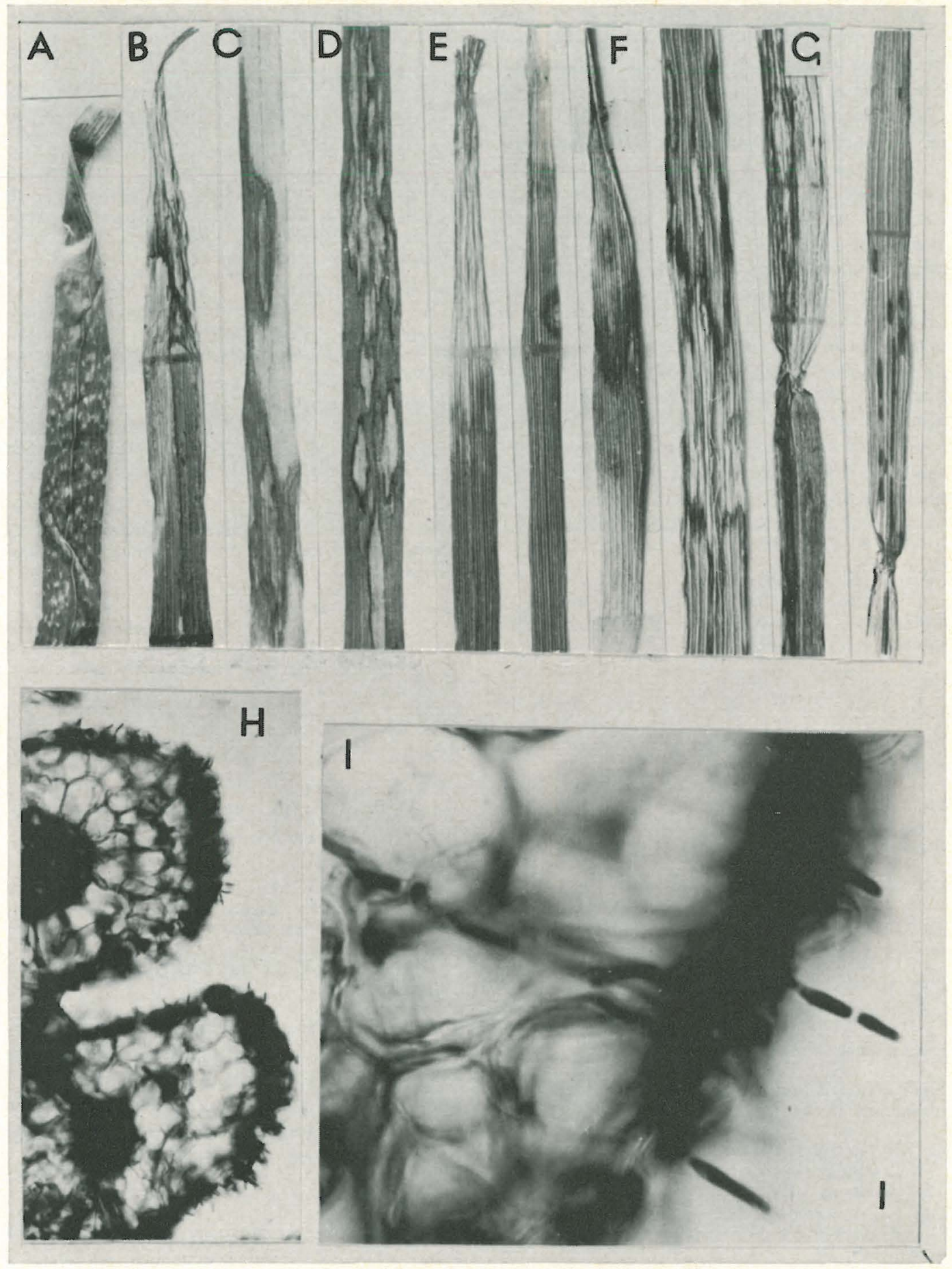

Fig. 2. Rhynchosporium orthosporum, A-G: lesions on leaves, $\mathrm{H}$, I: the fungus growing in tissue of a leaf, A-D: on Dactylis glomerata, E: on Festuca pratensis, F: on Phleum pratense, G: on Alopecurus pratensis, H, I: on Lolium perenne. A-G: x 1, H: x 100, I: x 1000. 
Occurrence of Rhynchosporium species during the growing season.

Rhynchosporium species were found throughout the growing season. Different grass species were quite similar in this respect. Conidia of the fungi were encountered in greatest abundance during the spring months, i.e. from April to May, with moderate occurrence also in autumn, whereas they were scarcest in midsummer. Viable conidia were found in abundance even as early in spring as the time when the snow still partly covered the leaves (even once in winter, on Jan. 13, 1971). Disease symptoms also were found most frequently in early spring and in autumn.

An important factor contributing to the frequent occurrence of Rhynchosporium species in this material is evidently the Finnish climate, its cool and humid spring and autumn as well as its long and snowy winter (cf. Kolkki 1966, Mäkelä 1972a). Numerous observations made elsewhere indicate that the diseases caused by fungi of Rhynchosporium are important only in the cooler part of the year (of. Brooks 1928, Jørstad 1930, Caldwell 1937, Braverman 1967). This has been the case on grasses (Lolium species, Dactylis glomerata) in Britain (THORPE 1960, Wilcox 1960) and in New Zealand (LATGH \& Wenham 1959, Latch 1966).

\section{Symptoms on grasses}

Rhynchosporium orthosporum caused on the leaves of grasses spots which varied in colour, shape and size even on the same grass species. The spots occurring on grass were in general clearly distinguishable from leaf blotch on barley, caused by $R$. secalis (cf. MäkelÄ 1972b). On the other hand, on many grass species (on Lolium spp., Festuca spp., Agrostis spp., and partly also on Phleum pratense) the symptoms caused by $R$. orthosporum were similar to those caused by the Helminthosporium species; the same applies to the spots caused by Spermospora spp. on Festuca rubra (cf. MäKELÄ 1971, 1972a). In this respect Dactylis glomerata and Alopecurus pratensis differed from the other grasses. On them symptoms caused by $R$. orthosporum were the most positively identifiable. Besides, very few Helminthosporium fungi occurred on both these grasses.

In early spring right after melting of the snow and for a time thereafter, leaves of grass containing conidia of $R$. orthosporum were mainly dead (Fig. 2 B, E). The apical parts of the leaves in particular were dead, being light orange white - greyish orange in colour. On Dactylis glomerata in the dead tissue there was often a white, granular coloration (Fig. 2 A). Below the light tip the colour turned darker: mustard brown, tobacco brown, bronze. On cocksfoot the colour was more reddish brown, on other grasses generally more greyish brown. When the grass started to grow, the sick leaves nearly disappeared (cf. Wilcox 1960). From the end of May to the end of June the grass stands were clearly healthy (cf. MäKelä \& Ilonoja 1971, MäKelä 1972a). Starting with the end of June the leaves, notably those of Dactylis glomerata, began to be increasingly tainted with spots caused by $R$. orthosporum (Fig. 2). The most common ones were vaguely-defined spots of different sizes which occurred here and there on the leaf, often joining together and killing a major portion of the tissue of the leaf (Fig. 2). Often leaves of this sort were also dead at the tip. On Dactylis glomerata and Phleum pratense the spots were most often rust brown - oak brown in hue, on Lolium and Festuca species, tobacco brown - greyish brown - grey in colour. Of lesser occurrence were spots that were grey - bluish grey in the middle and brown round the edges (Fig. 2 D) (cf. CALDWell 1937, OWen 1952, Smedegård-PeterSEN 1970). The size of blotches was on Dactylis glomerata (c. 1120 lesions) (1) 16 (135228) $\mathrm{mm}$ long, (1) 2.7 (7) $\mathrm{mm}$ wide and on Phleum pratense (c. 110 lesions) (5) 27 (32-135) mm long, (1) 2.2 (6) $\mathrm{mm}$ wide.

The spots which the Rhynchosporium fungus caused on Alopecurus pratensis were striking, particularly in early summer. In colour the spots were a vivid yellowish brown, golden brown, tobacco brown, chocolate brown, cocoa brown, sepia. Some of the spots went round the edge of the leaf, continuing to the sheath of the leaf (Fig. $2 \mathrm{G}$ ). The culm and the ear were also liable to damage. The size of lesions (about 70) was (2) 44 (120) $\mathrm{mm}$ long, (1) 1.6 (10) $\mathrm{mm}$ wide.

\section{Conidia}

Conidia of Rhynchosporium orthosporum were hyaline and generally two septa, though 3 (4) septa conidia occurred rather common- 


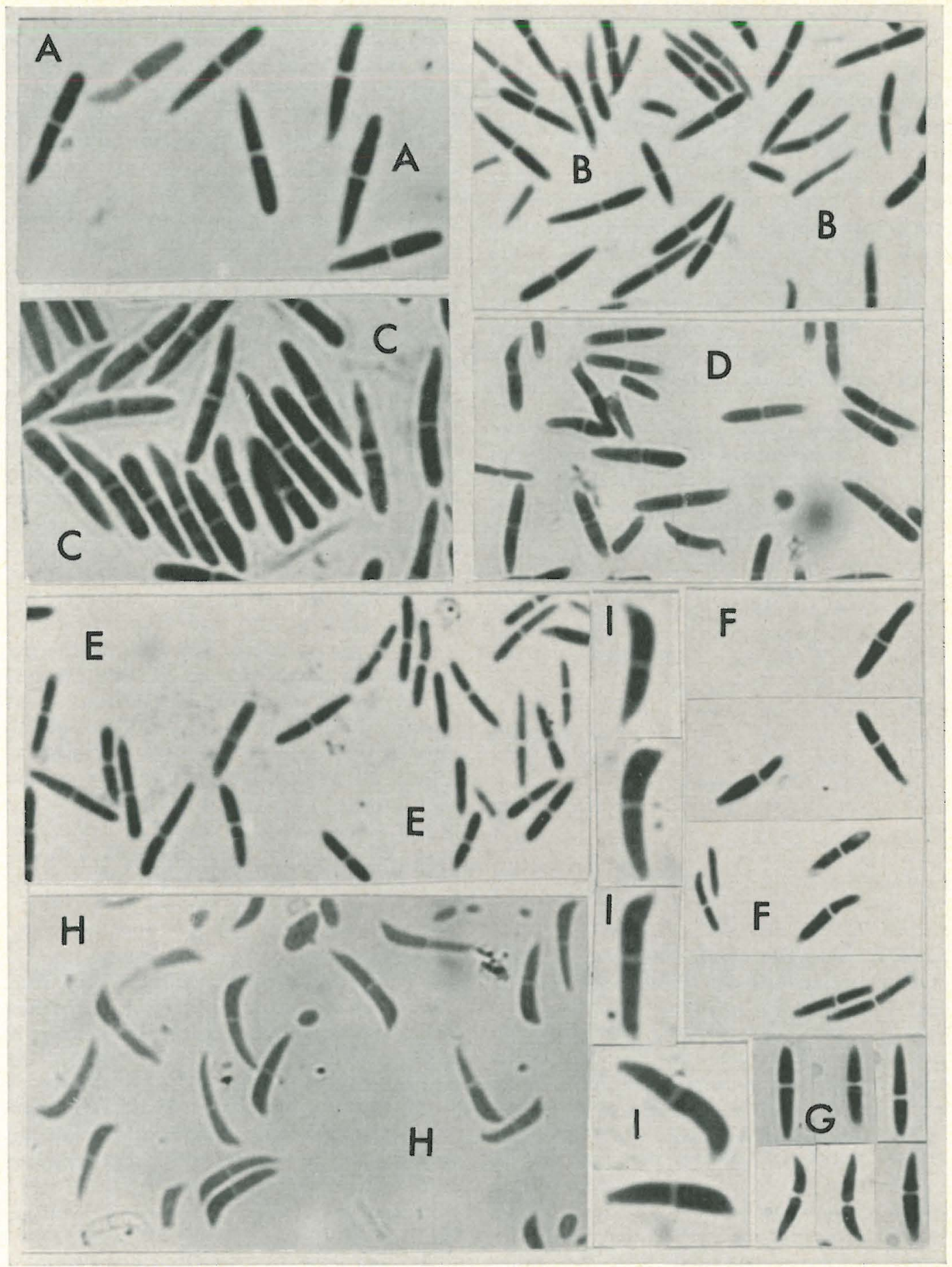

Fig. 3. Conidia of Rhynchosporium orthosporum A-G and R. secalis H, I. A-D: from Dactylis glomerata, E: from Festuca pratensis, F: from Phleum pratense, G: from Alopecurus pratensis, H, I: from Agropyron repens. A: Helsinki, Viikki 10. VI. 1968; B: Mikkeli 21. VII. 1969; C: Anjala 18. VII. 1969; D: Pälkäne 23. VII. 1969; E: Mikkeli 21. V. 1968; F: Hämeenlinna 11. V. 1968; G: Inari, Muddusniemi 14. VIII. 1969; H: Helsinki 17. V. 1968; I: Tyrväntö, Lepaa 5. VII. 1970. A, C, I: x 2000; B, D-H: x 1000. 

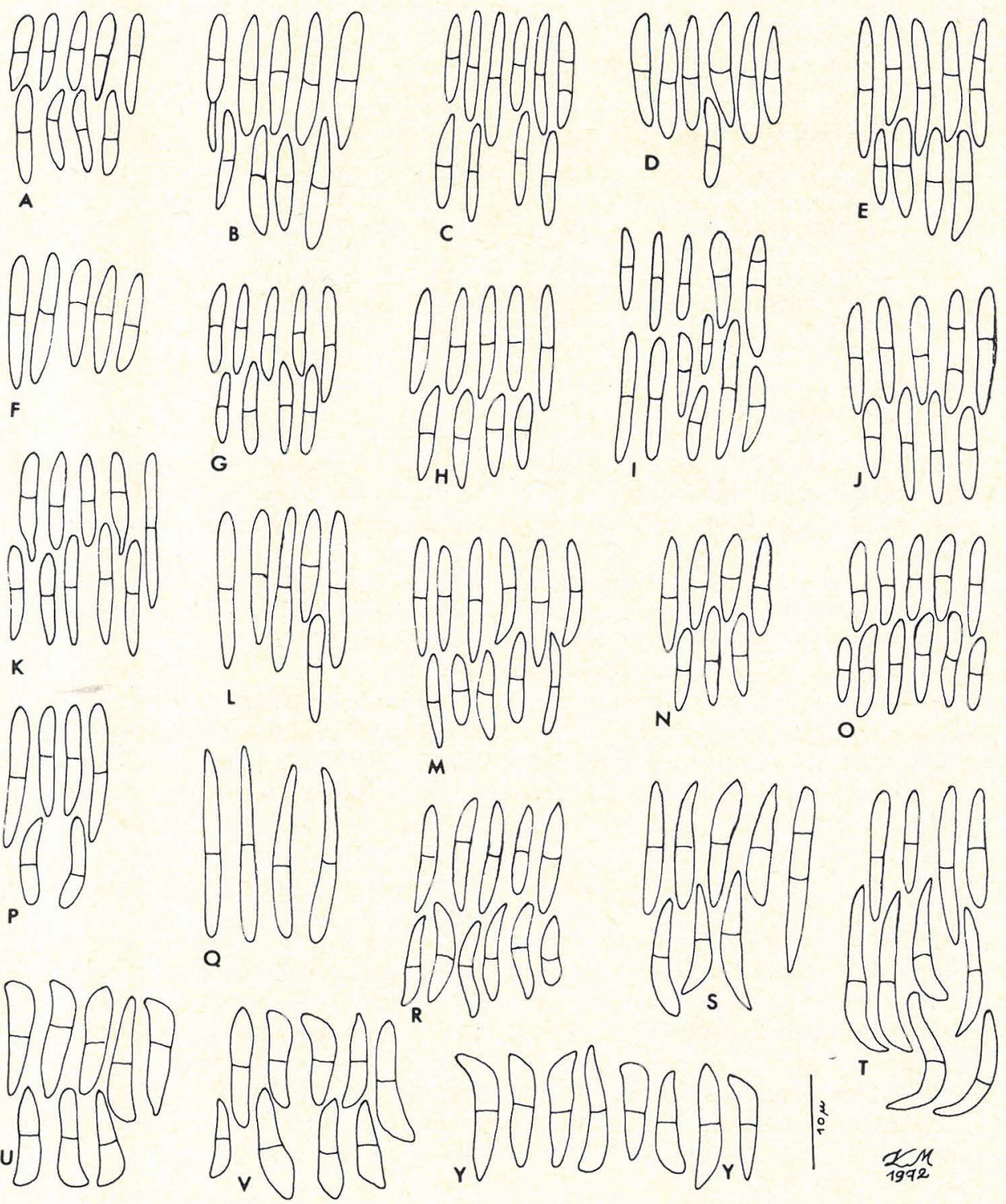

Fig. 4. Conidia of Rhynchosporium orthosporum, A-T and R. secalis, U-Y. A-E: from Dactylis glomerata, F-I: from Festuca pratensis, J-K: from Phleum pratense, L-M: from Lolium perenne, N-O: from Poa pratensis, P: from Agrostis stolonifera, $\mathrm{Q}$ from Calamagrostis arundinaceae, R-T: from Alopecurus pratensis, U-V: from Agropyron repens, Y: from Bromus inermis. Helsinki, Viikki: A, 11. V.1967; B, 23. X. 1967; I, 5. VI. 1967; L, 28. III. 1968; R, U, 17. V. 1968; Y, 26. V. 1967. Hyrylä: P, 29. V. 1970. Lohja: Q, 15. VIII. 1968. Hämeenlinna: G, 11. V. 1968; J, 13. IV. 1968; S, 23. VI. 1968; V, 3. XI. 1967. Peipohja: E, 15. X. 1968; M, N, 15. V. 1968. Mikkeli: F, 21. V. 1968. Inari, Muddusniemi: C, 28. VI. 1968; D, 1. IX. 1968; H, 21. VII. 1968; K, O, T, 1. IX. 1968. 
Table 1. Size of conidia of Rhynchosporium species on the different grasses.

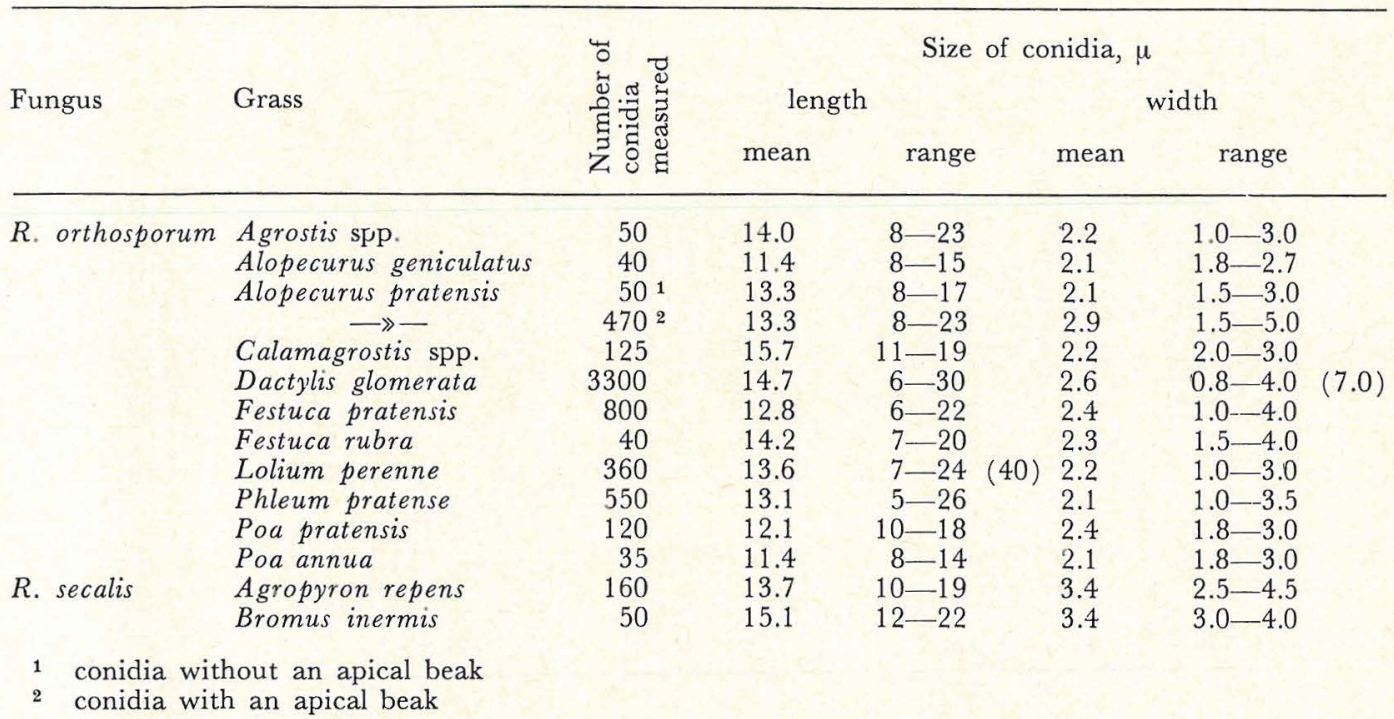

ly on Dactylis glomerata (cf. Sprague 1950). There were rather small differences in the size of the spores between the different species of grass (Table 1), though the spores growing on D. glomerata and on Calamagrostis species were relatively longer, whereas those growing on Poa species were relatively shorter. The shape of the spores varied somewhat depending on the species of grass and the growing conditions (Figs. 3, 4).

The spores of $R$. secalis were generally fatter two septa with a short apical beak (Figs. $3 \mathrm{H}, \mathrm{I}, 4 \mathrm{U}-\mathrm{Y}$ ).

In ail the samples gathered from Alopecurus pratensis there were spores similar to those of both $R$. orthosporum and $R$. secalis (Figs. $3 \mathrm{G}, 4 \mathrm{R}-\mathrm{T}$ ). In size, notably in width, they were closest to spores of $R$. orthosporum. The same phenomenon has also been observed by Sprague (1950).

In the present study the size and form of conidia of Rynchosporium species were same as in many other materials (cf. Caldwell 1937, Owen 1952, 1958, Latah \& Wenham 1959, SMEdegi̊nd-Petersen 1970).
Spores of the Rhynchosporium species were unobservable. Only when growing in highly favourable circumstances could the spores be seen growing in thick groups on the leaf surface. Conidiophores were not visible at all and mycelia of fungi were extremely scarce (Fig. 2 H, I) (cf. Brooks 1928, Caldwell 1937).

Acknowledgements. - I express my sincere thanks to Mrs. Eila Metsäpelto, M. Sc., Mrs. Aino Hanhilahti, Agr., Miss Riitta Lahtinen and Mrs. Hilkka Koponen, and also to many other persons for their technical assistance, e.g. in analysing plant specimens and measuring spores. I am thankful to Mr. PenttiHeinänen for photographing my microscopic slides and leaves of grasses. My thanks also to the Experiment Stations of the Agricultural Research Centre and the Plant Breeding Institute of Hankkija as well as to late Prof. Otto Valle for research materials. I am grateful to the University of Helsinki and to my late husband Dr. Aarne Mäkelä for their financial assistance.

\section{REFERENCES}

Anon. 1961. Jaarboek 1961. Versl. Pl-Ziekt. Dienst Wageningen 136. 248 p. (ref. Rev. Appl. Myc. 42: 295-296).

Bartels, F. 1928. Studien über Marssonina graminicola. Forsch. Gebiet Pfl.krankh. Immunität Pfl.reich 5: 73-114.
Braverman, S. W. 1967. Disease resistance in coolseason forage, range, and turf grasses. Bot. Rev. 33: 329-378.

Brien, R. M. 1942. First supplement to 'A list of plant diseases recorded in New Zealand'. N.Z.J. Sci. Tech., A, 24: 62-64. 
Brooks, F. T. 1928. Observations on Rhynchosporium secalis (Oud.) Davis, leaf blotch of barley and rye. New Phytol. 27, 4: 215219.

Caldwell, R. M. 1929. Preliminary results from cross inoculation and culture studies upon the fungus Rhynchosporium secalis (Oud.) Davis causing scald of cereals and other grasses. (Abstr.) Phytopathol. 19: 104.

- 1931. Host specialization and parasitism of the genus Rhynchosporium. (Abstr.) Phytopathol. 21: 109-110.

- 1937. Rhynchosporium scald of barley, rye, and other grasses. J. Agric. Res. 55: 175198.

Davis, J. J. 1919. Notes on parasitic fungi in Wisconsin VI. Wisc. Acad. Sci., Arts, Letters, Trans. 19: 705-727.

Drechsler, C. 1921. Occurrence of Rhynchosporium on Dactylis glomerata and Bromus inermis. (Abstr.) Phytopathol. 11:42.

Elliott, E. S. 1962. Disease damage in forage grasses. Phytopathol. 52: 448-451.

Fowler, A. M. \& Owen, H. 1964. New or uncommon plant diseases and pests. Rhynchosporium orthosporum on perennial ryegrass. Plant Pathol. 13: 94.

Hansen, L. R. \& Magnus, H. A. 1969. Leaf spot fungi on barley in Norway. Norwegian Plant Protec. Inst. Div. Plant Pathol., Vollebekk, Rep. No 42. Forskn. forsøk landbr. 20: $95-105$.

Howard, F. L., Rowell, J. B. \& KeIl, H. L. 1951. Fungus diseases of turf grasses. Bull. R. J. Agric. Exp. Sta. 308. 56 p.

Jørstad, I. 1930. Beretning om plantesykdommer i land- og hagebruket. VI. Sykdommer på korn- og engvekster. 84 p. Oslo.

- 1945. Parasittsoppene på kultur- og nyttevekster i Norge. I. Sekksporesopper (Ascomycetes) og konidiesopper (Fungi imperfecti). Medd. Stat. Plant Pathol. Inst. 142 p. Oslo.

Kajiwara, T. \& Iwata, Y. 1963. Studies on the strains of the barley scald fungus, Rhynchosporium secalis (Oud.) Davis. Bull. Nat. Inst. Agric. Sci. Tokyo, Ser. C, 15: 1-73. (ref. Rev. Appl. Myc. 43: 132-133.)

Kolkki, O. 1966. Tables and maps of temperature in Finland during 1931-1960. Suppl. Meteorol. Yearb. Finland 65, 1a: $1-42$.

Latch, G. C. M. 1966. Fungious diseases of ryegrass in New Zealand. N.Z.J. Agric. Res. 9: $394-409$

- \& Wenham, H. T. 1959. Fungal leaf-spot diseases of cocksfoot (Dactylis glomerata L.) in the Manawatu. N.Z.J. Agric. Res. 2: $544-551$.

LIND, J. 1913. Danish fungi as represented in the herbarium of E. Rostrup. 650 p. Copenhagen.

Lindau, G. 1910. Fungi imperfecti: Hyphomycetes in Rabenhorst, L. Kryptogamen-Flora von Deutschland, Oesterreich und der Schweiz. 1, 9, 983 p. Leipzig.

MÄkelä, K. 1970. The genus Mastigosporium Riess in Finland. Karstenia 11: 5-22.

- 1971. Some graminicolous species of Helminthosporium in Finland. Karstenia 12: $5-35$.

- 1972a. Disease damage to the foliage cultivated grasses in Finland. Acta Agr. Fennica $124,1: 1-56$.

- 1972b. Leaf spot fungi on barley in Finland. Acta Agr. Fennica 124, 3: 1-23.

- \& Ilonoja, P. 1971. Effects of nitrogen fertilization on disease damage to foliage of silage leys. Acta Agric. Scand. 21: $237-$ 248.

Mühle, E. 1953. Die Krankheiten und Schädlinge der zur Samengewinnung angebauten Futtergrässer. 167 p. Leipzig.

Oudemans, C. A. J. A. 1897. Observations Mycologiques. Kunk. Akad. Wetensch. Amsterdam 6: 86-92.

Owen, H. 1952. Leaf blatch of cocksfoot. Plant. Pathol. 1: 122.

Schein, R. D. 1958. Pathogenic specialization in Rhynchosporium secalis. Phytopathol. 48: $477-480$.

Skoropad, W. P. 1957. Temperature and humidity relationships in securing infection of barley with Rhynchosporium secalis (Abstr.) Phytopathol. 47: 32-33.

Smedegård-Petersen, V. 1970. Drechslera poae and Rhynchosporium orthosporum recorded as pathogens on grasses in Denmark. Horticultura 24: 38-46.

Sprague, R. 1946. Rootrots and leafspots of grains and grasses in the Northern Great Plains and Western States. Plant Dis. Reptr. Suppl. 163: 195, 202.

- 1950. Diseases of cereals and grasses in North America. 538 p. New York.

Thorpe, I. G. 1960. New or uncommon plant diseases. Rynchosporium secalis on Westerwolths ryegrass. Plant Pathol. 9: 111-114.

Wilcox, H. J. 1960. New or uncommon plant diseases. Rhynchosporium orthosporum on Italian ryegrass. Plant Pathol. 9: 111-114. 